\title{
DINAMIKA PMA DAN PMDN DI INDONESIA SEBAGAI \\ DAMPAK DARI UPAH MINIMUM, INFLASI DAN PDRB TAHUN 2004-2012: PENDEKATAN DYNAMIC PANEL DATA MODEL
}

\author{
Lea Widowati Sugiharto \\ Fakultas Ekonomi-IESP, Universitas Diponegoro \\ leaa.widowati@gmail.com \\ Akhmad Syakir Kurnia \\ Fakultas Ekonomi-IESP, Universitas Diponegoro \\ akhmadkurnia@undip.ac.id
}

\begin{abstract}
This paper aims at investigating the behavior of foreign direct investment (FDI) and domestic direct investment (DDI) in Indonesia, which is expected to be explained by several explanatory variables including the setting of regional minimum wage, inflation, as well as regional domestic product. More specifically, the investigation is focused on the effect of annual increase in the minimum regional wage, provided that it is a sensitive issue for investors. Using 33 provincial level data in a period from 2004 to 2012, this paper uses a dynamic panel data which allows us to see the behavior of direct investment in the short run as well as in the long run.The result shows that an increase in the regional minimum wage setting reduces both DDI and FDI in the short run. However, in the long run, an increase in the regional minimum wage is likely to increase both DDI and FDI. This is likely indicating that in the long run an increase in wage is expected to be accompanied by higher productivity, eventhough in the short run higher wage increases cost of production which will undermine investment.
\end{abstract}

Keywords:regional setting minimum wages, DDI and FDI, dynamic panel data.

\section{PENDAHULUAN}

Investasi merupakan aspek penting dalam perekonomian. Hal ini terjadi karena investasi merupakan komponen agregat demand yang paling tidak stabil dibanding dengan komponen agregat demand lainnya. Dengan demikian, investasi merupakan faktor yang mempengaruhi fluktuasi ekonomi. Investasi juga menjadi kanal penting yang menghubungkan suku bunga dengan ekonomi. Karena itu investasi memiliki peranan penting dalam transmisi kebijakan moneter. Dari sisi 
penawaran (supply side), investasi menjadi faktor penting dalam proses akumulasi stok modal dan menjadi faktor penting dalam mendorong pertumbuhan ekonomi.

Dari sisi investor, motivasi untuk melakukan investasi adalah keuntungan yang diharapkan. Investor akan mempertimbangkan keuntungan yang diharapkan dengan membandingkan keuntungan dan pengorbanan/beban yang dikeluarkan, dengan memperhitungkan setiap unit yang dinvestasikan, mempertimbangkan opportunity cost, faktor risiko, kemudahan perijinan usaha dan kepastian regulasi. Tingginya opportunity cost, faktor risiko dan ketidakpastian usaha akan mengurangi keinginan investor untuk melakukan investasi. Oleh karena itu, menjadi penting bagi pemerintah menciptakan iklim ekonomi yang ramah bagi investasi. Iklim yang ramah bagi kemudahan kegiatan investasi mencakup perijinan, kepastian regulasi, pajak, jaminan keamanan dan repatriasi keuntungan serta infrastruktur. Bagi Indonesia, faktor yang mempengaruhi iklim investasi tersebut masih harus terus diperbaiki. Survei Ease Of Doing Business 2014 masih menempatkan Indonesia pada urutan ke 120 dari 280 negara, jauh tertinggal dari negara-negara tetangga seperti Singapura (1), Malaysia (6), Thailand (17), Brunei Darussalam (59), Vietnam (99), Filipina (109).

Di satu sisi, pemerintah harus memperbaiki faktor-faktor yang menentukan kemudahan berusaha, pada saat yang sama Indonesia menghadapi tantangan terkait kenaikan upah buruh tiap tahunnya. Sebagaimana diketahui salah satu daya tarik investasi di Indonesia selama ini adalah murahnya harga faktor produksi buruh. Selama ini strategi industrialisasi di Indonesia sering dikonotasikan dengan strategi upah buruh murah untuk menarik investasi. Karena itu naiknya upah buruh menjadi faktor disinsentif bagi investor untuk melakukan investasi.

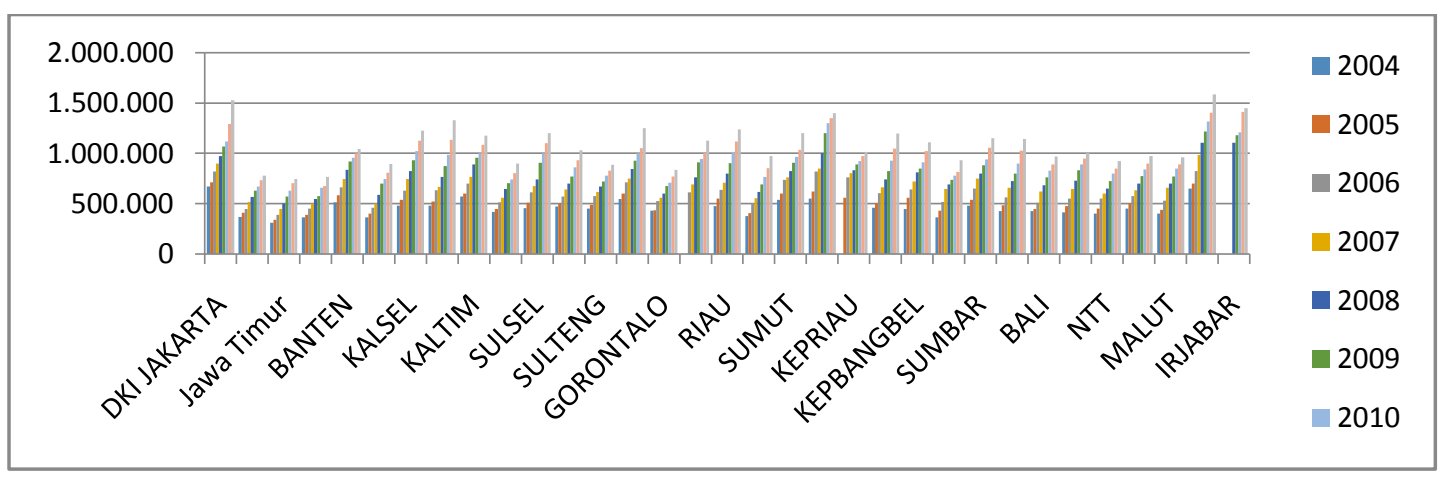

Sumber: Kementrian Tenaga Kerja dan Transmigrasi 2004-2013, diolah

\section{Grafik 1 \\ Grafik UMP di Indonesia \\ Tahun 2004-2012 (Rp)}

Disintensif naiknya upah buruh bagi investasi sudah barang tentu tidak menjadikan alasan untuk mempertahankan strategi upah buruh murah dalam menarik investasi. Hal ini karena strategi upah buruh murah mendatangkan nilai tambah yang 
kecil. Bagi Indonesia yang jumlah penduduknya besar, nilai tambah yang kecil bagi strategi industri dengan upah buruh murah memberikan efek kesejahteraan yang kecil terutama bagi rumah tangga buruh. Oleh karena itu, strategi upah buruh murah yang biasa diasosiasikan dengan tenaga kerja tidak terdidik (unskilled labor) dalam jangka panjang harus bisa bergeser ke arah strategi keunggulan komparatif dengan basis tenaga kerja terdidik (skilled labor) dan upah yang lebih tinggi diharapkan bisa memberikan nilai tambah yang lebih besar dan memberikan efek kesejahteraan yang lebih besar bagi penduduk.

Dari sisi pengusaha/investor upah yang dibayarkan tenaga kerja merupakan harga atas produktifitas tenaga kerja. Sehingga, kenaikan upah buruh tanpa diikuti naiknya tingkat produktifitas tenaga kerja akan memberatkan pengusaha dan menurunkan daya saing. Lebih jauh hal tersebut berpotensi menyebabkan menurunnya daya tarik untuk mempertahankan investasinya di Indonesia. Akibatnya kemudian adalah jumlah pengangguran meningkat disertai dengan kontraksi ekonomi.

Berkaitan dengan hal tersebut penetapan upah minimum provinsi tiap tahun di Indonesia oleh pemerintah menjadi momen kritis bagi buruh, pengusaha dan makroekonomi secara keseluruhan. Di satu sisi buruh menginginkan peningkatan upah namun disisi lain, pengusaha menuntut kenaikan produktifitas jika disertai peningkatan upah buruh. Kenaikan upah buruh melebihi tambahan produktifitas akan mengurangi tingkat investasi yang berakibat meningkatnya pengangguran.

Dengan latar belakang seperti yang telah dipaparkan, paper ini bertujuan untuk melihat perilaku investasi di Indonesia baik investasi domestik maupun investasi asing dalam merespon naiknya tingkat upah. Dengan mengadopsi model dynamic panel data, paper ini diharapkan dapat melihat dampak kenaikan upah dalam jangka pendek dan jangka panjang. Dengan observasi 33 provinsi di Indonesia selama periode waktu 2004-2012, estimasi yang dihasilkan model ini mampu menghilangkan bias agregasi dalam menggambarkan dinamika investasi di Indonesia sebagai respon atas naiknya upah buruh dan faktor determinan lainnya.

\section{RUMUSAN MASALAH}

Investasi mampu meningkatkan perekonomian suatu wilayah. Karena secara umum Indonesia merupakan salah satu tujuan negara bagi investor untuk melakukan investasi. Pemerintah secara khusus harus mempersiapkan kondisi ekonomi yang mampu menunjang investasi dan tenaga kerja, hal ini dimaksudkan agar roda perekonomian tetap berjalan. Investasi membutuhkan iklim usaha yang kondusif dan mempertimbangkan total pengeluaran dan total pendapatan. Beberapa faktor dapat mempengaruhi iklim usaha tersebut. Salah satunya adalah kenaikan tingkat upah melalui mekanisme upah minimum provinsi. Bagi buruh, naiknya tingkat upah memberikan kesejahtraan. Di sisi yang lain, upah menyebabkan naiknya ongkos 
produksi jika tidak diimbangi dengan produktifitas. Melalui yang telah disampaikan, maka dugaan sementara penelitian adalah investasi domestik maupun asing di Indonesia dipengaruhi oleh perubahan tingkat upah minimum, inflasi dan PDRB. Investor akan mempertimbangkan faktor tersebut untuk melakukan kegiatan investasi/penanaman modal. Penelitian ini akan melihat bagaimana dinamika dalam jangka pendek dan jangka panjang antara variabel yang mempengaruhi tingkat investasi tersebut.

\section{MANFAAT PENELITIAN}

Investasi merupakan faktor yang penting dalam pembangunan. Dinamika investasi dalam suatu perekonomian dipengaruhi oleh banyak variabel. Penelitian ini lebih spesifik bertujuan untuk meneliti dinamika jangka panjang dan jangka pendek investasi (PMA dan PMDN) sebagai akibat pemberian upah minimum yang ditetapkan pemerintah, inflasi dan PDRB. Harapan penulis, penelitian ini dapat bermanfaat sebagai berikut.

1. Sebagai bahan masukan bagi para pengambil kebijakan, dalam hal ini pemerintah setempat, yang berkaitan dengan kegiatan investasi dalam negeri di Indonesia.

2. Sebagai bahan referensi serta perbaikan untuk penelitian selanjutnya terkait dengan penelitian ini.

\section{KAJIAN PUSTAKA DAN PENGEMBANGAN HIPOTESIS}

\section{Teori Produksi}

Produksi adalah kegiatan yang merubah input menjadi output. Diasumsikan terdapat dua jenis faktor produksi yang digunakan untuk menghasilkan output. Barang input yang digunakan tersebut adalah $\mathrm{K}$ atau kapital (modal) serta $\mathrm{L}$ atau labor (tenaga kerja).

$\mathrm{Y}=\mathrm{f}(\mathrm{K}, \mathrm{L})$

\section{Biaya dan Kombinasi Faktor Jangka Panjang}

Faktor produksi berimplikasi pada biaya. Biaya merupakan sejumlah harga yang dikeluarkan produsen atas input yang digunakan. Faktor produksi kapital (K) biayanya adalah sewa (r) dan untuk faktor produksi tenaga kerja (L) biayanya adalah upah (w). Jika jumlah faktor produksi (K dan L) dikalikan dengan biaya faktor produksi ( $\mathrm{r}$ dan $\mathrm{w})$. Keseimbangannya adalah sebagai berikut:

$\mathrm{C}=\mathrm{r} \cdot \mathrm{K}+\mathrm{w} \cdot \mathrm{L}$

Tujuan perusahaan adalah memaksimalkan keuntungan. Fungsi laba adalah:

$\mathrm{Laba}=\mathrm{PY}-(\mathrm{r} \cdot \mathrm{K}+\mathrm{w} \cdot \mathrm{L})$ 
Dimana PY harga jual dikali input total. PY merupakan penerimaan total. r.K + w.L merupakan total biaya seperti yang telah disebutkan pada pembahasan sebelumnya. Pada jangka panjang, semua biaya kapital akan bervariasi. Investasi dipengaruhi oleh Total Revenue/pendapatan total (TR) dan Total Cost/pengeluaran total (TC). Produsen mempertimbangkan keuntungan pada TR $>$ TC.

\section{Marginal Rate Technical Of Substitution (MRTS)}

Perusaahaan akan menggunakan sejumlah faktor produksi tertentu untuk menghasilkan output pada tingkat keuntungan maksimal. MRTS dapat mengetahui jumlah output yang diciptakan atas penambahan satu faktor produksi.

Marginal Productifity of Labour $\left(\mathrm{MP}_{\mathrm{L}}\right)$ produk marginal tenaga kerja dan Marginal Productifity of Kapital $\left(\mathrm{MP}_{\mathrm{K}}\right)$ merupakan besarnya output tambahan yang dihasilkan oleh satu tambahan modal (L dan K).

$$
M P_{L}=f(K, L+1)-f(K, L)
$$

$\mathrm{f}(\mathrm{K}, \mathrm{L}+1)$ merupakan simbol untuk jumlah output yang dihasilkan jika menggunakan tambahan satu unit tenaga kerja. $f(K, L)$ merupakan simbol untuk jumlah output yang dihasilkan jika memproduksi dengan jumlah tenaga kerja yang sama (Mankiw, 2006).

$M P_{K}=f(K+1, L)-f(K, L)$

$\mathrm{f}(\mathrm{K}+1, \mathrm{~L})$ merupakan simbol dimana jumlah output yang dihasilkan oleh penambahan satu unit modal kapital. $\mathrm{f}(\mathrm{K}, \mathrm{L})$ merupakan jumlah output yang dihasilkan tanpa ada penambahan modal kapital (Mankiw 2006).

Perubahan biaya dapat mempengaruhi keuntungan. Perhitungannya adalah sebagai berikut:

$\Delta \mathrm{Laba}=\Delta$ Penerimaan $-\Delta$ Biaya

$\pi=\left(\mathrm{P} \times \mathrm{MP}_{\mathrm{K}}\right)-\mathrm{r}$

$\pi=\left(\mathrm{P} \times \mathrm{MP}_{\mathrm{L}}\right)-\mathrm{W}$

Menurut (Mankiw 2006) permintaan perusahaan terhadap tenaga kerja ditentukan oleh:

$\mathrm{P} \times \mathrm{MP}_{\mathrm{L}}=\mathrm{W}$

Atau dapat dituliskan kembali dengan,

$\mathrm{MP}_{\mathrm{L}}=\mathrm{w} / \mathrm{P}$ 


\section{Marginal effeciency of capital (MEC) dan Marginal Efficiency of Invesment (MEI)}

Marginal efficiency of capital (MEC) merupakan tingkat pengembalian yang diharapkan dari setiap tambahan barang modal (Rahardja dan Manurung 2008). MEC memperkirakan tingkat kelayakan gabungan investasi dengan mempertimbangkan antara tingkat pengembalian (rate of return), tingkat suku bunga pinjaman (yang diasumsikan tetap). Jika tingkat pengembalian diatas tingkat sukubunga per-tahun, maka investasi layak dilanjutkan.

Marginal Efficiency of Investment (MEI) mengasumsikan tingkat suku bunga berubah-ubah tiap waktu (Sukirno 2000). Gambaran dari MEI adalah seberapa besar tingkat investasi dan apakah tingkat pengembaliannya melebihi atau sama dengan tingkat suku bunga pinjaman (Sukirno 2000). Hubungan antara investasi dengan suku bunga adalah negatif. Artinya semakin besar tingkat suku bunganya maka semakin menurun tingkat investasinya. Namun terdapat pengecualian dimana tingkat investasi mampu meningkat seiring dengan peningkatan sukubunga. Beberapa hal yang mempengaruhi keadaan tersebut misalnya baiknya pembangunan ekonomi, kemajuan teknologi dan lain-lain.

\section{Akselerasi Fleksibel}

Akselerasi fleksibel adalah melakukan rencana peningkatan stok modal. Akselerasi fleksibel mengutamakan hasil dan waktu. Hal tersebut dilakukan untuk mengupayakan peningkatan secara cepat tingkat pendapatan nasional,sehingga dibutuhkan tambahan modal dalam jumlah besar dan waktu yang singkat. Teori akselerator fleksibel membedakan jenis stok modal pada waktu tersebut, yakni stok modal yang diperlukan dan stok modal yang tersedia (Sukirno 2000).

\section{Hipotesis}

Hipotesis pada penelitian adalah sebagai berikut.

H1: Terdapat hubungan kointegrasi antara variabel dependen dengan variabel dependennya.

Namun pada proses jangka pendek lebih bersifat tidak equilibrium, tetapi dapat dikoreksi dengan tingkat persentase tertentu.

Dugaan analisis pada hubungan antara variabel yang telah dilakukan estimasi:

a. PMA

- Diduga terdapat hubungan negatif antara variabel upah minimum provinsi (UMP) terhadap Penanaman Modal Asing (PMA).

- Diduga terdapat hubungan negatif antara Inflasi dengan PMA.

- Diduga terdapat hubungan positif antara Produk Domestik Regional Bruto (PDRB) terhadap PMA. 


\section{b. PMDN}

- Diduga terdapat hubungan negatif antara variabel upah minimum provinsi (UMP) terhadap Penanaman Modal Dalam Negeri (PMDN).

- Diduga terdapat hubungan negatif antara Inflasi dengan PMDN.

- Diduga terdapat hubungan positif antara Produk Domestik Regional Bruto (PDRB) terhadap PMDN.

c. Diduga terdapat proses kointegrasi panel pada variabel independen terhadap dependen. Terdapat proses ECM panel yang terkoreksi pada nilai persen tertentu.

\section{METODA PENELITIAN}

\section{Sampel dan Data Penelitian}

1. Investasi

Investasi adalah kegiatan memproduksi barang output untuk menghasilkan keuntungan dikemudian hari. Investasi membutuhkan barang modal untuk menghasilkan barang/jasa. Seperti yang dipaparkan Gilarso (2004), penanaman modal/investasi merupakan kegiatan menyisihkan sebagian dana yang digunakan membeli barang produksi. Peningkatan ketersediaan barang modal dan keuntungan dapat berubah tiap periode waktu. Perusahaan mampu memproduksi dan memfungsikan modal/peralatan baru, yang dampaknya akan mempengaruhi ekspektasi/harapan dimasa mendatang (Case dan Fair 2007).

Terdapat dua jenis investasi menurut badan usaha. Jenis investasi tersebut adalah Penanaman Modal Asing (PMA) dan Penanaman Modal Dalam Negeri (PMDN). PMA dalam undang-undang No.25 tahun 2007, merupakan kegiatan usaha menanam modal yang dilakukan di wilayah negara Republik Indonesia yang dilakukan oleh penanam modal asing. PMA merupakan perusahaan yang melakukan perluasan jaringan perusahaan di tempat (negara) lain. Ciri-ciri PMA adalah segala kebijakan manajemen seringkali sangat bergantung pada manajemen ditingkat paling tinggi, dalam hal ini adalah kantor pusat di negara asal (Tjandraningsihet al., 2008). Kebijakan tersebut misalnya adalah pengaturan hubungan antara buruh atau dengan pemimpin masyarakat dengan perusahaan.

PMDN dalam undang-undang No.25 tahun 2007 merupakan kegiatan melakukan usaha di wilayah Republik Indonesia. Kegiatannya dilakukan oleh penanaman modal dalam negeri dengan menggunakan modal dalam negeri. Data realisasi PMA dan PMDN tahun 2004-2012 diperoleh melalui badan koordinasi penanaman modal (BKPM).

2. Upah dan Upah Minimum Provinsi

Upah merupakan kewajiban/pengorbanan yang dikeluarkan pengusaha atas jasa buruh. Upah menurut peraturan pemerintah RI nomor 8 tahun 1981 merupakan 
suatu penerimaan imbalan pengusaha kepada buruh untuk suatu pekerjaan atau jasa yang telah atau akan dilakukan dan dibayarkan berdasarkan suatu perjanjian antara pengusaha dan buruh, termasuk tunjangan untuk buruh sendiri maupun keluarganya.

Upah minimum (UM) berdasarkan Peraturan Menteri Tenaga Kerja No. 7 tahun 2013, "adalah upah bulanan terendah yang terdiri atas upah pokok termasuk tunjangan tetap yang ditetapkan gubernur sebagai jaringan pengaman”. Penetapan UM di Indonesia didasarkan pada kebutuhan hidup layak (KHL) dengan memperhatikan produktifitas dan pertumbuhan ekonomi. Disisi lain penetapan UM oleh pemerintah menyebabkan tingkat upah riil menjadi tinggi. Upah rill menjadi tidak sesuai dengan produktifitas karyawan.

Pemerintah menetapkan upah minimum adalah bukan tanpa alasan. Simanjuntak (1998) mengatakan bahwa kebijakan Upah Minimum adalah:

1. menjamin penghasilan pekerja agar tidak lebih atau kurang dari tingkat tertentu;

2. meningkatkan produktivitas pekerja;

3. meningkatkan efisiensi perusahaan dengan menerapkan pengembangan dan peningkatan cara produksi lebih efisien.

Data UMP tahun 2004-2012 pada penelitian ini diperoleh melalui kementrian tenaga kerja dan transmigrasi.

3. Inflasi

Inflasi merupakan suatu keadaan dimana harga barang naik. Kenaikan harga barang terjadi secara umum pada pasar barang/jasa. Kenaikan harga secara umum dapat berdampak pada meningkatnya harga kebutuhan pokok. Kenaikan tingkat inflasi yang tinggi berakibat pada masyarakat secara keseluruhan. Misalnya, bagi pengusaha meningkatnya harga barang kebutuhan produksi mengakibatkan pengeluaran biaya modal yang juga meningkat. Sementara itu bagi masyarakat secara umum, tingkat inflasi mengakibatkan daya beli masyarakat menjadi rendah.

Penyebab inflasi adalah demand-pull inflation dan cost-push inflation (Mankiw 2006). Demand-pull inflation disebabkan oleh kelebihan permintaan. Potensi pemegang uang yang semakin besar, semakin ingin orang membelanjakan uangnya, maka kelangkaan dipasar akan semakin terjadi. Cost-push inflation disebabkan karena adanya kenaikan biaya produksi dan barang produksi. Data inflasi tahun 2004-2012 diperoleh melalui Badan Pusat Statistik (BPS).

\section{Produk Domestik Regional Bruto (PDRB)}

Produk domestik regional bruto (PDRB) merupakan penjumlahan nilai tambah (value added) barang/jasa dalam perekonomian suatu daerah di waktu tertentu. PDRB dinyatakan atas dasar harga berlaku (nominal) dan harga konstan (riil). PDRB atas dasar harga konstan (rill) berarti melihat besaran output yang dihasilkan dengan memproyeksikannya dengan harga yang berlaku pada tahun tersebut. PDRB atas harga berlaku (nominal) menggunakan harga tahun dasar, atau 
yang berarti perhitungannya menggunakan satu tahun harga dasar untuk dijadikan acuan. Perhitungannya adalah dengan membagi antara PDRB nominal dengan inflasi lalu dikalikan dengan 100 persen. Penelitian ini mengacu pada PDRB atas dasar harga konstan (riil). Data PDRB tahun 2004-2012 diperoleh melalui badan pusat statistik (BPS).

\section{MODEL PENELITIAN}

Penelitian ini menggunakan observasi dengan data panel. Penelitian ini melakukan analisis dalam jangka panjang dan jangka pendek. Dengan demikian maka jenis penelitian adalah dynamic panel data model. Estimasi data panel adalah sebagai berikut:

$\mathrm{PMA}_{i \mathrm{it}}=\beta_{0 \mathrm{i}}+\beta_{1} \mathrm{UMP}_{\mathrm{it}}+\beta_{2}$ INFLASI $_{\mathrm{it}}+\beta_{3} \mathrm{PDRB}_{\mathrm{it}}+\mu_{\mathrm{it}}$

$\mathrm{PMDN}_{\mathrm{it}}=\gamma_{0 \mathrm{i}}+\gamma_{1} \mathrm{UMP}_{\mathrm{it}}+\gamma_{2} \mathrm{INFLASI}_{\mathrm{it}}+\gamma_{3} \mathrm{PDRB}_{\mathrm{it}}+\varepsilon_{\mathrm{it}}$

Keterangan:

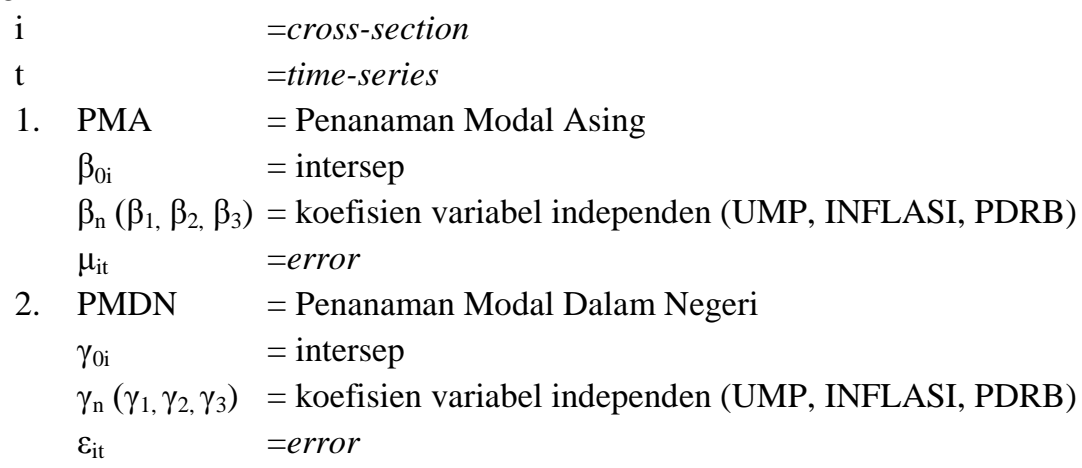

\section{Estimasi Regresi Panel Data dengan Random Effect Model (REM)}

Alasan mengapa penelitian ini menggunakan estimasi dengan REM adalah sebagai berikut.

1. Menghindari terbatasnya degree of freedom jika menggunakan fixed effect model. FE memasukkan variabel dummy kedalam model. Hal ini membuat variabel pada model menjadi sangat banyak jika obeservasi juga berjumlah sangat banyak. Variabel dummy juga dapat menyebabkan perangkap dummy. Dimana intersep antara variabel dummy dengan intersep variabel basis tidak dihilangkan salah satunya. Hal ini menyebabkan terjadinya multikolinearitas yang menyebabkan korelasi antara variabel independen.

2. Error spesifik individu (unobservable individual spesific effect) bersifat random,

3. ECM merupakan keseimbangan jangka pendek yang mensyaratkan adanya hubungan kointegrasi antar variabel. Estimasi dalam jangka pendek sebelumnya dilakukan setelah melakukan estimasi jangka panjang. Estimasi jangka panjang 
yang dilakukan secara random yang kemudian akan membuat sifat ECM menjadi random.

Model persamaan estimasi random effect adalah sebagai berikut:

$$
\mathrm{Y}_{\mathrm{it}}=\beta_{1}+\Sigma_{r=1}^{3} \beta_{\mathrm{r}} \mathrm{X}_{\mathrm{rit}}+\mu_{\mathrm{it}}+\varepsilon_{\mathrm{i}}
$$

Keterangan :

$\mathrm{Y}_{\mathrm{it}} \quad=$ Variabel dependen.

$\beta_{1} \quad=$ Intersep.

$\Sigma_{r=1}^{3} \beta_{\mathrm{r}} \mathrm{X}_{\mathrm{rit}} \quad=$ Slope dari masing-masing variabel independen.

$\mu_{\mathrm{it}} \quad=$ Komponen error pada panel data.

$\varepsilon_{\mathrm{i}} \quad=$ Komponen error pada unobservable individual spesific effect.

Estimasi dengan data panel ini juga merupakan hasil untuk mengetahui koefisien dalam jangka panjang (cointegration equation).

\section{Uji Stasioneritas Panel Data}

Tujuan pengujian stasioner adalah untuk membuktikan data yang tidak stasioner. Data yang tidak stasioner menjadi tidak masalah selama variabel berkointegrasi dan sebaliknya, data yang tidak stasioner tetapi juga tidak terkointegrasi dapat menyebabkan regresi lancung. Regresi lancung adalah hasil estimasi yang sebenarnya tidak memiliki makna apapun (Winarmo 2011).

Penelitian ini menggunakan uji Im, Pessaran dan Shin. Uji Im, Pessaran dan Shin (uji IPS) menurut Sanjoyo (2006) adalah sebagai berikut:

1. uji ini sudah mempertimbangkan karakteristik korelasi residual (residual serial correlation) dan dynamics heterogen untuk data panel,

2. dapat mengakomodasi heterogenitas antar kelompok (misal, individual spesial effect),

3. lebih tepat digunakan jika terdapat efek spesifik individu maupun heterogenitas cross-group dimana ketika menggunakan data panel terjadi persoalan perubahan struktur pada data cross-section yang panjang.

Uji IPS menggunakan rata-rata uji ADF ketika $\mu_{\mathrm{it}}$ berkorelasi dengan serial korelasi antar cross section. Jika Ho diterima, maka tiap seri panel data yang diuji terdapat akar-akar unit. Menolak $\mathrm{H}_{\mathrm{o}}$ berarti tidak ada akar-akar unit. Uji untuk $\mathrm{H}_{1}$ (Baltagi 2005):

$$
H_{1}: \begin{gathered}
\rho_{1}<0 \text { untuk } i=1,2, \ldots, N_{1} \\
\rho_{1}=0 \text { untuk } i=N_{1}+1, \ldots, N
\end{gathered}
$$

Uji IPS membutuhkan pembagian time-series yang stasioner menjadi nol, lim $\mathrm{n} \rightarrow \infty\left(\mathrm{N}_{1} / \mathrm{N}\right)=\delta$ dimana $0<\delta$. Keadaan ini penting untuk konsistensi dalam uji akar unit. IPS t-bar statistik mendefinisikan rata-rata dalam ADF statistik, yakni (Baltagi 2005): 


$$
\bar{t}=\frac{1}{N} \sum_{i=1}^{N} t_{p i}
$$

Dimana $t_{p i}$ adalah t-statistik untuk tiap individu cross-section.

Pada kondisi umum dimana lag order $\rho_{\mathrm{i}}$ adalah nol untuk beberapa crosssection. Hasil pada $\mathrm{t}$ adalah berbeda untuk tiap cross-section untuk setiap intersep dan tren linier. IPS memperlihatkan dengan baik standart distribusi $\bar{t}$. Dimulai dari mengenal hasil pada time series untuk N yang tetap (Baltagi 2005):

$$
t_{p i} \Rightarrow \frac{\int_{0}^{1} W_{i Z} d W_{i Z}}{\left[\int_{0}^{1} w_{i Z}^{2}\right]^{2}}=t_{i T}
$$

Dimana $\int \mathrm{W}(\mathrm{r})$ menunjukkan Weiner integral. IPS berasumsi $t_{i T}$ memiliki batas rata-rata dan varian. Lalu:

Saat $\mathrm{N} \rightarrow \infty$ menghitung dengan teorema central limit Lindeberg-Levy, dikarenakan:

$$
\begin{gathered}
\frac{\sqrt{N}\left(\frac{1}{N} \sum_{i=1}^{N} t_{i T}-\frac{1}{N} E\left[t_{i T} \mid \rho_{i}=0\right]\right)}{\sqrt{\frac{1}{N} \sum_{i=1}^{N} \operatorname{var}\left[t_{i T} \mid \rho_{i}=0\right]}} \Rightarrow N(0,1) \ldots \ldots . . . \\
I P S=\frac{\sqrt{N}\left(\bar{t}-\frac{1}{N} \sum_{i=1}^{N} E\left[t_{i T} \mid \rho_{i}=0\right]\right)}{\sqrt{\frac{1}{N} \sum_{i=1}^{N} \operatorname{var}\left[t_{i T} \mid \rho_{i}=0\right]}} \Rightarrow N(0,1)
\end{gathered}
$$

$\mathrm{T}$ adalah percontohan bagi $\mathrm{N}$, saat nilai $\mathrm{T} \rightarrow \infty$ maka $\mathrm{N} \rightarrow \infty$. Hasil dari $\mathrm{E}\left[t_{i T} \mid \rho_{i}=0\right]$ dan $\operatorname{var}\left[t_{i T} \mid \rho_{i}=0\right]$ sudah dihitung dalam uji IPS, nilainya bisa dilihat pada perbedaan nilai $\mathrm{T}$ dan $p_{i}$. Hasil penelitian Im Pessaran dan Shin memuaskan dan umumnya lebih baik dari pengujian yang lain. Hanya dengan sampel yang kecil namun dapat menunjukkan orderlag yang cukup baik.

\section{Uji Kointegrasi Panel}

Fungsi uji ini adalah mengetahui apakah anatara variabel dependen dan independen memiliki hubungan dalam jangka panjang atau tidak. Uji kointegrasi data panel dalam penelitian ini menggunkan uji Pedroni. Uji Pedroni untuk kointegrasi panel diklasifikasikan menjadi dua kategori. Pertama melibatkan nilai rata-rata statistik untuk kointegrasi pada data time-series terhadap cross-section. Kedua, rata-rata dilakukan secara individu pada tiap anggota (cross-section) (Baltagi 2005).

Uji pedroni menjelaskan hasil kointegrasi yang menerima heterogenitas. Terdiri dari dua kategori, bagian pertama dengan menggunakan statistik Philips dan Ouliaris.

$$
\hat{Z}_{p}=\sum_{i=1}^{N} \frac{\sum_{t=1}^{T}\left(\hat{e}_{\mathrm{it}-1} \Delta \hat{e}_{\mathrm{it}}-\hat{\lambda} i\right)}{\sqrt{\left(\Sigma_{t=1}^{T} \hat{e}_{\mathrm{it}-1}^{2}\right)}}
$$


Dimana terdapat estimasi $\hat{e}_{i t}$ dari persamaan $\hat{\lambda}=\frac{1}{2}\left(\hat{\sigma}^{2}{ }_{\mathrm{i}} \hat{-}^{2}{ }_{\mathrm{i}}\right)$, untuk beberapa $\hat{\sigma}_{i}^{2}$ dan $\hat{s}_{i}^{2}$ adalah jangka panjang dan merupakan hal yang sejalan dengan $\hat{e}_{i t}$. Bagian kedua Pedroni mendefinisikan varian rasio panel statistik, menjadikan $\widehat{\Omega}_{\mathrm{i}}$ estimasi yang konsisten pada $\Omega_{i}$ pada jangka panjang matrik kofarians. Menemukan $\hat{L} i$ untuk menjadi tringular Cholesky komposisi pada $\widehat{\Omega}_{\mathrm{i}}$ adalah pada lingkup $\hat{L}_{22 \mathrm{i}}=\hat{\sigma}_{\varepsilon}$ dan $\widehat{L}_{11 \mathrm{i}}$ $=\hat{\sigma}_{\mathrm{u}}^{2}-\hat{\sigma}_{\mathrm{u} \varepsilon}^{2} / \hat{\sigma}_{\varepsilon}^{2}$ pada kondisi jangka panjang, modelnya menjadi:

$$
Z_{\mathrm{t} \hat{\mathrm{pNT}}}=\frac{\Sigma_{i=1}^{N} \Sigma_{t=2}^{T} \hat{L}_{11 i}^{-2}\left(\hat{e}_{\mathrm{it}}-1 \Delta \hat{e}_{\mathrm{it}}-\hat{\lambda} \imath\right)}{\sqrt{\hat{\sigma}^{2} \mathrm{NT}\left(\Sigma_{i=1}^{N} \Sigma_{t=2}^{T} \hat{L}_{11 i}^{-2} \hat{e}_{\mathrm{it}-1}^{2}\right)}}
$$

Dimana , $\hat{\sigma}_{\mathrm{NT}}=\frac{1}{N} \sum_{i-1}^{N} \frac{\widehat{\sigma}^{2}}{\widehat{L}_{11 i}^{2}}$

Uji Pedroni berdasarkan pada istilah pembilang dan penyebut tetapi bukan menggunakan rata-rata untuk statistik secara keseluruhan. Menggunakan hasil gerak fungsi konvergensi Brown, Pedroni menemukan hasil:

$\mathrm{Z}_{\mathrm{t}} \hat{P}_{\mathrm{NT}}+1.73 \sqrt{N} \rightarrow \mathrm{N}(0,0.93)$

Konvergensi atau penggabungan pada distribusi merupakan dasar konvergensi individu untuk pembilang dan penyebut. Penolakan hipotesis menggunakan rata-rata dari semua uji statistik dan mengikuti intepretasinya (Baltagi 2005).

Penolakan hipotesis menggunakan rata-rata perhitungan statistik keseluruhan. Menolak hipotesis berarti memiliki nilai statistik jauh dari yang diprediksi oleh teori dan menghasilkan dibawah nol.

\section{Error Correction Model (ECM) Panel Data}

ECM merupakan model yang digunakan untuk menganalisis hubungan jangka pendek. Jika variabel memiliki hubungan dalam jangka panjang, maka asumsi dalam jangka pendek adalah variabel tidak memiliki hubungan yang equilibrium. Dengan demikian ECM mensyaratkan antar variabel agar memiliki hubungan kointegrasi.

Turunan ECM ini diadaptasi oleh Thomas (1997). Dijelaskan bahwa suatu permodelan ekonometrika, pasti menemukan suatu kondisi ketika variabel berada pada keseimbangan. Namun di kondisi lain suatu variabel juga bisa pada keadaan tidak seimbang dengan variabel lainnya (dis-equilibrium). Kondisi tersebut adalah kondisi yang terjadi pada suatu waktu tertentu, sehingga pada waktu tertentu model ekonometrika tidak akan lepas dari suatu lag yang menuju pada suatu model keseimbangan.

Dalam jangka panjang atau pada hubungan equilibrium antara dua variabel $\mathrm{X}$ dan Y adalah sebagai berikut:

$$
\mathrm{Y}_{\mathrm{it}}=\mathrm{KX}_{\mathrm{it}}{ }^{\beta 1}
$$


$\mathrm{K}$ dan $\beta_{1}$ adalah konstan. $\beta_{1}$ merupakan jangka panjang dari variabel $\mathrm{Y}$ dengan melalui $X$, sehingga ketika ditulis kembali menjadi:

Model tersebut menjelaskan bahwa $\mathrm{y}_{\mathrm{it}}=\ln \mathrm{Y}_{\mathrm{it}} ; \beta_{0}{ }^{*}=\ln (\mathrm{K})$ dan $\beta_{1} \mathrm{x}_{\mathrm{it}}=\beta_{1} \ln \mathrm{X}$.

$$
\begin{aligned}
& y_{i t}=\beta_{0}{ }^{*}+\beta_{1} x_{i t} \\
& y_{i t}-\beta_{0}{ }^{*}-\beta_{1} x_{i t}
\end{aligned}
$$

Persamaaan tersebut menyatakan bahwa terdapat hubungan keseimbangan atau terdapat hubungan pada jangka panjang. Jika y dan $\mathrm{x}$ seimbang maka kesalahan ketidakseimbangan bernilai nol. Pada nyatanya y dan $\mathrm{x}$ jarang seimbang. Kesalahan ketidakseimbangan dapat digambarkan sebagai berikut:

Dari yang telah dipaparkan, kenyataan bahwa y dan $\mathrm{x}$ jarang mencapai keseimbangan dapat tergambarkan pada kondisi jangka pendek. Kondisi jangka pendek yang dis-equilibrium, selalu menyertakan nilai lag pada y dan $\mathrm{x}$, sehingga keseimbangan menjadi:

$$
\mathrm{y}_{\mathrm{it}}=\mathrm{b}_{0}+\mathrm{b}_{1} \mathrm{x}_{\mathrm{it}}+\mathrm{b}_{2} \mathrm{x}_{\mathrm{it}-1}+\mu \mathrm{y}_{\mathrm{it}-1}+\mathrm{e}_{\mathrm{it}}
$$

$\mu \mathrm{y}_{\mathrm{it}-1}$ merupakan penyesuaian kesalahan (error correction).

Permasalahan kemudian adalah jika data tidak stasioner, maka berarti harus mengatur kembali model dengan memasukan $y_{i t-1}$ pada 3.14 dan menambah $\beta_{1} x_{i t-1}$ pada persamaan selanjutnya.

$$
\begin{aligned}
& y_{i t-} y_{i t-1}=b_{0}+b_{1} x_{i t}+b_{2} x_{i t-1}-(1-\mu) y_{i t-1}+e_{i t} \\
& y_{i t-y_{i t-1}}=b_{0}+b_{1} x_{i t}-b_{1} x_{i t-1}+b_{1} x_{i t-1}+b_{2} x_{i t-1}-(1-\mu) y_{i t-1}+e_{i t}
\end{aligned}
$$

atau,

$$
\Delta \mathrm{y}_{\mathrm{it}}=\mathrm{b}_{0}+\mathrm{b}_{1} \Delta \mathrm{x}_{\mathrm{it}}+\left(\mathrm{b}_{1}+\mathrm{b}_{2}\right) \mathrm{x}_{\mathrm{it}-1}-\lambda \mathrm{y}_{\mathrm{it}-1}+\mathrm{e}_{\mathrm{it}}
$$

Dimana $\lambda=1-\mu$, maka persamaan menjadi:

$\Delta \mathrm{y}_{\mathrm{it}}=\mathrm{b}_{0}+\mathrm{b}_{1} \Delta \mathrm{x}_{\mathrm{it}}-\lambda\left(\mathrm{y}_{\mathrm{it}-1}-\beta_{1} \mathrm{x}_{\mathrm{it}-1}\right)+\mathrm{e}_{\mathrm{it}}$

Maka menghasilkan parameter baru yakni: $\beta_{1}=\left(b_{1}+b_{2}\right) / \lambda$ dan $\beta_{0}=b_{0} / \lambda$

$$
\Delta y_{i t}=b_{1} \Delta x_{i t}-\lambda\left(y_{i t-1}-\beta_{0}-\beta_{1} x_{i t-1}\right)+e_{i t}
$$

Dari persamaan 28, keseimbangan ECM kemudian dijabarkan oleh oleh Sargan (1964) pada persamaan 29, kemudian dipopulerkan oleh Engle dan Grenger. Dengan menggunakan tiga variabel penjelas, persamaan model ECM ini dapat paparkan sebagai berikut (Winarno 2009):

$\Delta \mathrm{Y}_{\mathrm{it}}=\mathrm{b}_{0}+\mathrm{b}_{1} \Delta \mathrm{X}_{1 \mathrm{it}}+\mathrm{b}_{2} \Delta \mathrm{X}_{2 \mathrm{it}}+\mathrm{b}_{3} \Delta \mathrm{X}_{3 \mathrm{it}}+\mathrm{b}_{4} \mathrm{ECT}_{\mathrm{it-1}}+\varepsilon_{\mathrm{it}}$ 
Dan untuk persamaan ECT adalah:

$\mathrm{ECT}=\mathrm{Y}_{\mathrm{it}-1}-\beta_{1} X_{\mathrm{it}-1}-\beta_{2} \mathrm{X}_{2 \mathrm{it}-1}-\beta_{3} \mathrm{X}_{3 \mathrm{it}-1}$

Melalui persamaan 29 dan 30 bahwa $\mathrm{Y}_{\text {it }}$ merupakan investasi (PMA dan PMDN) panel data. $\Delta \mathrm{X}_{\text {rit }}$ merupakan tiga jenis variabel yang diteliti. Persamaan ECT it-1 pada persamaan 30, mengoreksi kesalahan semua variabel melalui keseimbangan jangka pendek. ECT $_{\text {it-1 }}$ merupakan koreksi kesalahan atau residual lag satu dari persamaan awal. Model koreksi kesalahan sudah benar jika nilai statistik t diatas dua dan nilai probabilita <0,05 (Winarno 2009).

\section{PEMBAHASAN}

\section{Analisis Statistik Deskriptif}

\section{Uji Stasioner Panel}

Tabel 1

Ringkasan Hasil Im, Pesaran and Shin (IPS)

\begin{tabular}{llll}
\hline Variabel & $\begin{array}{l}\text { Hasil uji level (p- } \\
\text { val) }\end{array}$ & $\begin{array}{l}\text { Hasil } \\
1^{\text {st }} \text { difference }\end{array}$ & $\begin{array}{l}\text { Uji } \\
2^{\text {nd }} \text { difference }\end{array}$ \\
\hline PMA & 0,9989 & 0,0000 & - \\
PMDN & 0,9998 & 0,0000 & - \\
UMP & 1,0000 & 0,0000 & - \\
INFLASI & 0,0000 & - & - \\
PDRB & 1,0000 & 0,9967 & 0,0000 \\
\hline Sumber: Eviews hasil perhitungan data panel, diolah
\end{tabular}

Hasil yang tertera pada Tabel 1 menyatakan bahwa hanya variabel Inflasi saja yang stasioner pada tingkat awal. Variabel PMA, PMDN dan UMP sudah stasioner pada derajat pertama, namun untuk variabel PDRB stasioner saat derajat ke dua.

\section{Uji Kointegrasi Panel}

Hasil uji pada Tabel 2, baik within-dimension maupun between-dimension menyatakan terdapat hubungan kointegrasi antar variabel, namun hanya panel PPstat pada kolom within-dimension yang menyatakan tidak terkointegrasi.

Tabel 2

Ringkasan Hasil Uji Kointegrasi Panel PMA

\begin{tabular}{lccccl}
\hline & Statistic & Prob. & Statistic & Prob. & Keterangan \\
\hline Within-dimension & & & & & \\
Panel PP-Stat. & 2,533172 & 0,9943 & $-6,653633$ & 0,0000 & Tolak Ho: $\alpha=5 \%$ \\
Panel ADF-Stat. & $-9,312502$ & 0,0000 & $-5,300543$ & 0,0000 & Tolak Ho: $\alpha=5 \%$ \\
$\begin{array}{l}\text { Between-dimension } \\
\text { Panel PP-Stat. }\end{array}$ & $-8,669442$ & 0,0000 & & & Tolak Ho: $\alpha=5 \%$ \\
Panel ADF-Stat. & $-5,743649$ & 0,0000 & & & Tolak Ho: $\alpha=5 \%$ \\
\hline
\end{tabular}

Sumber: Eviews hasil perhitungan data panel, diolah 
Hasil uji kointegrasi panel pada Tabel 3, PMDN, baik pada kolom withindimension maupun kolom between-dimension menyatakan terdapat hubungan kointegrasi antar variabel. Namun hanya panel ADF-stat pada kolom betweendimension yang menyatakan tidak terkointegrasi.

Tabel 3

Ringkasan Hasil Uji Kointegrasi Panel PMDN

\begin{tabular}{lccccl}
\hline & Statistic & Prob. & Statistic & Prob. & Keterangan \\
\hline Within-dimension & & & & & \\
Panel PP-Stat. & $-10,90261$ & 0,0000 & $-11,55515$ & 0,0000 & Tolak Ho: $\alpha=5 \%$ \\
Panel ADF-Stat. & $-3,920511$ & 0,0000 & $-3,717475$ & 0,0001 & Tolak Ho: $\alpha=5 \%$ \\
$\begin{array}{l}\text { Between-dimension } \\
\text { Panel PP-Stat. }\end{array}$ & $-15,99879$ & 0,0000 & & & \\
Panel ADF-Stat. & $-0,830285$ & 0,2032 & & & Tolak Ho: $\alpha=5 \%$ \\
\hline
\end{tabular}

Sumber: Eviews hasil perhitungan data panel, diolah

Setelah beberapa pengujian dilakukan, selanjutnya akan dilakukan estimasi keseimbangan kointegrasi panel dan koreksi kesalahan (ECM) dalam jangka pendek melalui regresi panel.

\section{Estimasi Regresi Data Panel (estimasi cointegration equation)}

Dari hasil yang telah diperoleh pada estimasi jangka panjang Tabel 4 bahwa kenaikan Rp1,- UMP akan menyebabkan kenaikan PMA sebesar USD55.000. Pengaruh statistik adalah signifikan atau menolak Ho pada $\alpha=$ lima persen. Kenaikan satu persen inflasi akan menyebabkan kenaikan PMA sebesar USD801.142. Namun pengaruh statistik jangka tidak signifikan atau menerima Ho dengan $\alpha=$ lima persen. Hasil estimasi jangka panjang kenaikan Rp1.000.000.000,- PDRB menyebabkan kenaikan PMA sebesar USD9.160. Pengaruh statistik adalah signifikan atau menolak Ho pada $\alpha=$ lima persen.

Tabel 4

Hasil Regresi Random Effect Model Panel Data PMA

\begin{tabular}{llllll}
\hline Variabel & Coefficient & Std. Error & t-statistic & Prob. & Keterangan \\
\hline C & $-653931,3$ & 167326,4 & $-3,908119$ & 0,0001 & \\
UMP & 0,557781 & 0,152864 & 3,648864 & 0,0008 & Tolak Ho: $\alpha=5 \%$ \\
INFLASI & 8011,421 & 6720.538 & 1,192080 & 0,2342 & Terima Ho: $\alpha=5 \%$ \\
PDRB & 9,163265 & 0,795732 & 11,51552 & 0,0000 & Tolak Ho: $\alpha=5 \%$ \\
R-squared & 0,354566 & & & & \\
Adjst R-square & 0,347958 & & & & \\
F-statistik & 53,65272 & & & & \\
Prob (F-stat) & 0,000000 & & & & \\
\hline
\end{tabular}

Sumber: Eviews hasil perhitungan data panel, diolah

Hasil Tabel 5 pada keseimbangan jangka panjang, kenaikan Rp1,- UMP menyebabkan kenaikan PMDN di Indonesia sebesar Rp1.850.000,-. Pengaruh statistik adalah signifikan atau menolak Ho dengan $\alpha=$ lima persen. Kenaikan satu persen inflasi menyebabkan penurunan PMDN sebesar Rp-1.759.309,- pada 
keseimbangan jangka panjang. Pengaruh statistik adalah menerima Ho atau tidak signifikan pada $\alpha=$ lima persen. Kenaikan Rp1.000.000.000,- PDRB akan menyebabkan kenaikan PMDN sebesar Rp23.360.000 juta dalam jangka panjang. Pengaruh statistik adalah signifikan atau menolak Ho dengan $\alpha=$ lima persen.

Tabel 5

Hasil Regresi Random Effect Model Panel Data PMDN

\begin{tabular}{llllll}
\hline Variabel & Coefficient & Std. Error & t-statistic & Prob. & Keterangan \\
\hline C & -1512864 & 443552,0 & $-3,410793$ & 0,0007 & \\
UMP & 1,852401 & 0,425014 & 4,358445 & 0,0000 & Tolak Ho $\alpha=5 \%$ \\
INFLASI & $-1759,309$ & 19326,06 & $-0,091033$ & 0,9275 & Terima Ho $\alpha=5 \%$ \\
PDRB & 23,36123 & 1,693692 & 13,79308 & 0,0000 & Tolak Ho $\alpha=5 \%$ \\
R-squared & 0,395521 & & & & \\
Adjst R-square & 0,389332 & & & & \\
F-statistik & 63,90500 & & & & \\
Prob (F-stat) & 0,000000 & & & & \\
\hline
\end{tabular}

Sumber: Eviews hasil perhitungan data panel, diolah

\section{Estimasi Keseimbangan Jangka Pendek (error correction model)}

Hasil estimasi Tabel 6 menunjukkan bahwa kenaikan Rp1,- UMP akan menyebabkan PMA turun sebesar USD-79.000. Pengaruh statistiknya tidak signifikan atau menerima Ho pada $\alpha=$ lima persen. Kenaikan satu persen inflasi akan menyebabkan kenaikan penanaman modal asing di Indonesia sebesar USD882.026. Pengaruh statistik adalah signifikan atau menolak Ho dengan $\alpha=5$ persen. kenaikan Rp1.000.000.000 PDRB akan menyebabkan kenaikan PMA sebesar USD11.450. Pengaruh statistik adalah signifikan atau menolak Ho dengan $\alpha=$ lima persen. Dalam jangka pendek model ini dapat diseimbangkan kembali sebesar 35 persen.

Tabel 6

Ringkasan Hasil ECM pada PMA

\begin{tabular}{llllll}
\hline Variabel & Coefficient & Std. Error & t-statistic & Prob. & Keterangan \\
\hline C & 96969,49 & 74060,47 & 1,309329 & 0,1916 & \\
DUMP & $-0,796429$ & 0,834863 & $-0,953963$ & 0,3410 & Terima Ho: $\alpha=5 \%$ \\
DINFLASI & 8820,261 & 4068,256 & 2,168069 & 0,0311 & Tolak Ho: $\alpha=5 \%$ \\
DPDRB & 11,93783 & 5,403052 & 2,209461 & 0,0280 & Tolak Ho: $\alpha=5 \%$ \\
ECT & $-0,352085$ & 0,045468 & $-7,743561$ & 0,0000 & Tolak Ho: $\alpha=5 \%$ \\
R-squared & 0,201533 & & & & \\
Adjst R-square & 0,189201 & & & & \\
F-statistik & 16,34289 & & & & \\
Prob (F-stat) & 0,000000 & & & & \\
\hline
\end{tabular}

Sumber: Eviews hasil perhitungan data panel, diolah

Pada Tabel 7 dijangka pendek, kenaikan Rp1,-UMP menyebabkan penurunan PMDN di Indonesia sebesar Rp-3.800.000,-. Pengaruh statistik tidak signifikan atau menerima Ho pada $\alpha=$ lima persen. Kenaikan satu persen inflasi menyebabkan peningkatan PMDN sebesar Rp4.860.823,-. Pengaruh statistik adalah menerima Ho atau tidak signifikan pada $\alpha=$ lima persen. kenaikan Rp1.000.000.000 Miliar PDRB 
mengakibatkan kenaikan PMDN sebesar Rp30.530.000,- Juta. Pengaruh statistik adalah menerima Ho atau tidak signifikan pada $\alpha=$ lima persen. ECM akan menyesuaikan kembali pada keseimbangan. PMDN akan menyesuaikan pada variabel independen sebesar 55 persen.

Tabel 7

Ringkasan Hasil ECM pada PMDN

\begin{tabular}{llllll}
\hline Variabel & Coefficient & Std. Error & t-statistic & Prob. & Keterangan \\
\hline C & 181202,3 & 233539,3 & 0,775897 & 0,4385 & \\
DUMP & $-0,381043$ & 2,620189 & $-0,145426$ & 0,8845 & Terima Ho: $\alpha=5 \%$ \\
DINFLASI & 4860,823 & 12827,38 & 0,378941 & 0,7050 & Terima Ho: $\alpha=5 \%$ \\
DPDRB & 30,52686 & 17,54144 & 1,740271 & 0,0830 & Terima Ho: $\alpha=5 \%$ \\
ECT & $-0,553506$ & 0,058898 & $-9,397772$ & 0,0000 & Tolak Ho: $\alpha=5 \%$ \\
R-squared & 0,248578 & & & & \\
Adjst R-square & 0,236973 & & & & \\
F-statistik & 21,41991 & & & & \\
Prob (F-stat) & 0,00000 & & & & \\
\hline
\end{tabular}

Sumber: Eviews hasil perhitungan data panel, diolah

\section{SIMPULAN, KETERBATASAN DAN IMPLIKASI}

\section{Simpulan}

Berdasarkan hasil analisis dan intepretasi secara ekonomi yang telah dilakukan pada bagian sebelumnya, penelitian ini menghasilkan simpulan sebagai berikut.

1. Kenaikan UMP menurunkan PMA namun tidak signifikan pada jangka pendek. Sementara kenaikan UMP meningkatkan PMA dengan signifikan pada jangka panjang. Kenaikan inflasi meningkatkan PMA dengan signifikan pada jangka pendek dan tidak signifikan pada jangka panjang. Selanjutnya, kenaikan PDRB juga meningkatakan PMA dengan signifikan pada jangka pendek dan jangka panjang.

2. Ketidakseimbangan PMA pada jangka pendek mampu dikoreksi sebesar 35 persen.

3. Kenaikan UMP akan mengurangi PMDN dengan tidak signifikan pada jangka pendek. Namun kenaikan UMP akan menaikan PMDN dengan signifikan pada jangka panjang. Kenaikan inflasi akan meningkatkan PMDN dengan tidak signifikan pada jangka pendek. Kenaikan inflasi di jangka panjang akan menurunkan PMDN dengan tidak signifikan. Selanjutnya naiknya PDRB akan meningkatkan PMDN dengan tidak signifikan pada jangka pendek dan dengan signifikan jangka panjang.

4. Ketidakseimbangan dalam jangka pendek, mampu diperbaiki sebesar 55 persen. 
Dalam jangka pendek penetapan UMP mampu menegaskan dampak negatif penetapan UMP. Hal yang berbeda ditunjukkan dalam jangka panjang, dimana meningkatnya penetapan UMP diharapkan sesuai dengan produktivitas tenaga kerja yang lebih tinggi.

Hasil penelitian ini menunjukkan bahwa penanam modal cenderung melihat kenaikan harga sebagai dasar untuk meningkatkan produksi dalam jangka pendek. Namun dalam jangka panjang, tingkat inflasi yang tinggi dinilai sebagai risiko yang tinggi oleh PMDN, sehingga mengurangi investasi.

Seperti yang diharapkan, hasil PDRB berpengaruh positif terhadap PMA dan PMDN baik dalam jangka pendek dan jangka panjang. Hal ini menunjukkan bahwa penanaman modal terus berlangsung seiring dengan peningkatan kapasitas perekonomian.

\section{Keterbatasan dan Saran}

\section{Keterbatasan}

Keterbatasan penelitian ini adalah variabel suku bunga kredit tidak dapat ditemukan setelah tahun 2007. Sebab suku bunga kredit tiap provinsi tidak bervariasi antar provinsi.

\section{Saran}

Dari beberapa uraian yang telah disampaikan sebelumnya, peneliti mampu memberikan saran sebagai berikut.

1. Pembuatan UMP kemudian mampu menjembatani antar kepentingan kaum buruh dengan kaum pengusaha. Namun demikian harus menjadi pertimbangan dalam mencari solusi terbaik. Sebab tidak bisa dipungkiri masih terdapat hambatan bagi penanam modal asing dan dalam negeri. Bahwa dalam jangka panjang, UMP merupakan beban tanpa diimbangi dengan produktifitas.

2. Pemerintah juga harus melaksanakan fungsinya sebagai stabilisator yang kemudian harus menjaga stabilnya tingkat inflasi tiap tahunnya. Menjaganya melalui pengawasan-pengawasan agar harga-harga tetap terkendali terhadap faktor-faktor yang menyebabkan peningkatan inflasi (misal: gangguan distribusi, peningkatan harga faktor produksi dan lain-lain) sehingga tingginya inflasi tidak sampai menggangu pengusaha dan konsumen. Karena bagaimanapun, tingkat inflasi pada nilai tertentu mampu mengurangi tingkat penanaman modal pada PMDN dijangka panjang.

3. Pertumbuhan tingkat PDRB tiap tahunnya menjadi gambaran peningkatan kinerja produsen dan rumah tangga dalam perekonomian. Kinerja tersebut adalah penciptaan output baru. Peningkatan output baru tersebut diharapakan peningkatan yang dilakukan pengusaha-pengusaha baru dan pengusaha lama yang lebih jeli melihat perkembangan kegiatan ekonomi. 


\section{DAFTAR PUSTAKA}

Baltagi, B. H. 2005. Econometric Analysis of Panel Data (3 ed.). England: Wiley.

Case, K. E., dan R. C. Fair. 2007. Prinsip-Prinsi Ekonomi (Y. A. Zaimur, Trans. H. W. Hardani \& D. Barnadi Eds.). Jakarta: Penerbit Erlangga.

Gujarati, D. N., danD. C. Porter. 2012. Basic Econometrics. Jakarta: Penerbit Salemba Empat.

Mankiw, N. G. 2006. Makro Ekonomi. Jakarta: Penerbit Erlangga.

Rahardja, P., danM. Manurung. 2008. Pengantar Ilmu Ekonomi (3 ed). Jakarta: LPFEUI.

Saputra, M. J., A. Setiawan, dan T. Mahatma. 2007. Analisis kointegrasi data runtut waktu indeks harga konsumen beberapa komoditas barang kota di jawa tengah. Program Studi MIPA UKSW.

Sukirno, S. 2000. Makroekonomi Modern (1 ed.). Jakarta: PT Raja Grafindo Persada.

Tjandraningsih, I., H. Nugroho, dan S. Tjandra. 2008. Buruh Vs. Investasi (Mendorong Peraturan Perburuhan yang Adil). Bandung: Yayasan AKATIGA.

Winarmo, W. W. 2011. Analisis Ekonometrika Dengan Eviews (3 ed). Yogyakarta: UUP STIM YKPN.

Winarno, W. W. 2009. Analisis Ekonometrika dan Statistika dengan EViews (2 ed). Yogyakarta: UPP STIM YKPN. 


\section{Lampiran}

\section{Uji Asumsi Klasik}

\section{Normalitas}

Penelitian ini menggunakan uji normalitas dengan mengamati nilai J-B dan probability value. Nilai Jarque-Bera tiap variabel per-provinsi memiliki rata-rata nilai probabilita yang menerima Ho dimana nilainya $>0,05$, artinya terdistribusi normal meski hanya beberapa yang memiliki nilai J-B yang lebih besar dari dua. Probabilita value yang dihasilkan tiap provinsi untuk tiap variabel memiliki rata-rata yang tidak signifikan dengan nilai signifikan $\alpha=$ lima persen. Dari pengamatan tersebut dinyatakan bahwa residual berdistribusi normal.

\section{Multikolinearitas}

Tabel8

\begin{tabular}{llll}
\multicolumn{4}{c}{ Koefisien Korelasi } \\
\hline & INFLASI & PDRB & UMP \\
\hline INFLASI & 1,000 & $-0,074$ & $-0,383$ \\
PDRB & $-0,074$ & 1,000 & 0,016 \\
UMP & $-0,383$ & 0,016 & 1,000 \\
\hline \multicolumn{2}{c}{ Sumber: Eviews7 }
\end{tabular}

\section{Heterokedastisitas}

Permasalahan pada heterokedastisitas adalah residual memiliki varian yang tidak konstan untuk tiap individu cross-section. Seperti yang dinyatakan oleh (Gujarati dan Porter 2012) tentang sifat khusus koefisien korelasi. Dijelaskan bahwa untuk setiap residual yang dimiliki individu dalam cross-section harus memiliki nilai yang sama dari beberapa waktu. Kemudian selanjutnya, struktur korelasi adalah identik untuk tiap subjek unit cross-section.

Jika hal tersebut kemudian tidak digunakan dalam estimasi panel data, maka estimator menjadi tidak efisien. Menurut (Gujarati dan Porter 2012)metoda yang pantas untuk mengakomodasi hal ini adalah metodaGLS (Generalized Least Squared). Mekanisme estimasi data panel, sudah diakomodasi dengan GLS. Sehingga telah jelas bahwa fungsi GLS disini adalah untuk mengakomodasi efek heterokedastisitas.

\section{Autokorelasi}

Menurut Gujarati dan Porter (2012) variabel yang tidak stasioner faktor kesalahannya mengandung autokorelasi. Kemudian yang terjadi dalam penelitian ini adalah tidak stasionernya data menjadi tidak begitu bermasalah sebab penelitian ini juga merujuk pada keseimbangan jangka pendek yang kemudian akan diperbaiki dengan ECT. ECT berada dalam keseimbangan ECM, namun kemudian ECM mensyaratkan kointegrasi, dengan demikian kejadian non-stasioneritas yang 
disebabkan masa lalu (pada lag tertentu) menjadi hal yang wajar. "Dalam konsep kointegrasi, dua variabel yang tidak stasioner akan terkointegrasi bila kombinasinya juga linier" (Saputraet al., 2007).

\section{Uji Statistik}

\section{Uji T}

Tabel 9

Ringkasan Hasil uji t-statistik

\begin{tabular}{llll||lll}
\hline & \multicolumn{3}{c}{ t-statistik } & p-value & t-statistik & p-value \\
\hline 1. PMA & C & $-3,91$ & 0,01 & 2. PMDN & $-3,41$ & 0,00 \\
kointegrasi & UMP & 3,65 & 0,00 & kointegrasi & 4,36 & 0,00 \\
& INFLASI & 1,19 & 0,23 & & $-0,09$ & 0,93 \\
& PDRB & 11,52 & 0,00 & & 13,79 & 0,00 \\
\hline ECM & C & 1,30 & 0,19 & ECM & 0,78 & 0,44 \\
& DUMP & $-0,95$ & 0,34 & & $-0,15$ & 0,88 \\
& DINFLASI & 2,17 & 0,03 & & 0,37 & 0,71 \\
& DPDRB & 2,21 & 0,03 & & 1,74 & 0,08 \\
& ECM & $-7,74$ & 0,00 & & $-9,40$ & 0,00 \\
\hline
\end{tabular}

Sumber: Eviews hasil perhitungan data panel, diolah

\section{Uji F}

Diketahui bahwa hasil estimasi uji $\mathrm{F}$ pada PMA keseimbangan kointegrasi sebesar 53,65 dan keseimbangan ECM sebesar 16,34. Sedangkan uji F pada keseimbang PMDN, hasil estimasi kointegrasi sebesar 63,91 dan pada ECM sebesar 21,42 .

\section{Uji $\mathbf{R}^{2}$}

Hasil determinasi $\mathrm{R}^{2}$ pada PMA dalam keseimbangan kointegrasi memiliki kemampuan untuk mejelaskan sebesar 0,35. Dalam keseimbangan ECM, kemampuan menjelaskannya sebesar 0,20 . Kemudian untuk hasil $\mathrm{R}^{2}$ yang dimiliki oleh PMDN dalam keseimbangan kointegrasinya memiliki kemapuan menjelaskan sebesar 0,39. Dalam keseimbangan ECM kemampuan menjelaskannya sebesar 0,24. 
